сев.-русск. - северно-русские диалекты

татар. - татарский язык

фин. - финский (суоми) язык

франц. - французский язык

эст. - эстонский язык

яросл. - русские диалекты Ярославской области

\title{
3. Прочие
}

диал.- диалектное

литер.- литературное

несов.- несовершенный вид

ср.- сравни

субстр.- субстратное

т. д.- так далее

\section{«ВОСХИЩЕНИЕ» В РАЗНЫХ КУЛЬТУРНЫХ ТРАДИЦИЯХ}

\section{М.А. Головцова, А.А. Шунейко}

Ключевые слова: коммуникация, коммуникативные формы, культура, культурные традиции, восхищение, комплимент.

Keywords: communication, communicative forms, culture, cultural traditions, admiration, compliment.

\section{DOI 10.14258/filichel(2019)1-13}

Исследование языковых картин мира занимает существенное место в современных лингвистических работах. К этим исследованиям обращаются Л. Вайсгербер, А.Д. Шмелев, Ю.Д. Апресян, Е.С. Яковлева, В.И. Постовалова и другие. Методологический аппарат подобных исследований включает в себя рассмотрение концептов, которое проводится с использованием концептуального, семантического и сопоставительного анализов (Н.Д. Арутюнова, В.А. Успенский, Н.С. Новиков, Н.В. Черемисина и другие). В рамках этой научной парадигмы представляется целесообразным рассмотреть нормативные способы выражения восхищения в русском и китайском языках как существенные сегменты, отражающие специфику национального менталитета и языковых картин в целом. Репрезентации способов выражения восхищения воспринимаются в 
работе как целостные семантические комплексы, отражающие содержательные и эмоциональные константы восприятия мира двумя народами [Иванова, 2017].

Вопросы выражения восхищения занимают особое место в исследованиях проблем коммуникации. В области эмотивной лингвистики создано большое количество научных работ. Из отечественных лингвистов, чьи труды посвящены категоризации эмоций, проблемам их вербализации, можно назвать таких ученых как Л.Г. Бабенко, В.И. Шаховский, С.Н. Погожая, Е.Ю. Мягкова, И.В. Труфанова, Е.В. Фирсова и другие.

Семантика «восхищения» наиболее полно и последовательно проявляется в комплименте. Комплимент (лестное замечание в адрес кого-либо), бесспорно, является наиболее эффективным методом налаживания контакта и опорой для дальнейшего успешного взаимодействия. Комплимент напрямую влияет на адресата, его относят к контактной межличностной коммуникации. Комплимент включает в себя коммуникативную цель, отношение говорящего, обстановку, языковое выражение, эмоциональную окраску. Выражение восхищения непосредственно связано с комплиментом, поскольку является составляющей его содержания. Исследователи данного речевого акта сходятся во мнении, что основная цель комплимента - это выражение положительных эмоций, оценки достоинств собеседника, восхищения отличительными особенностями адресата [Чертыкова, 2017]. Тем не менее, проблемы выражения восхищения являются недостаточно изученными на сегодняшний момент. Так, нами была выявлена только одна работа, связанная с сопоставительным изучением функционирования комплиментов в русском и китайском языках [Салахова, Дань Ма, 2015]. В ней авторы проводят анализ коммуникативных неудач, связанных с формулировкой комплимента и целями их использования в речи русскими и китайскими коммуникантами.

Данная работа анализирует специфику значений слова «восхищение» в русской и китайской лингвокультурах, основываясь на его словарной трактовке.

Толковый словарь живого великорусского языка В.И. Даля [Даль, 2001] определяет слово «восхищение» как состояние восторга, неистовой радости. В толковом словаре А.П. Евгеньевой [Евгеньева, 1957-1960] «восхищение» объясняется как высшая степень удовлетворения, удовольствия от чего-либо, восторг. Словарь современного русского литературного языка 
К.С. Горбачевича [Горбачевич, 1991, с. 503] предлагает следующее значение - высшая степень проявления радости, состояние очарованности кем-либо, чем-либо, восторг. В толковом словаре С.И. Ожегова [Ожегов, 2011] «восхищение» - это высшее удовлетворение, восторг. Толковый словарь Т.Ф. Ефремовой [Ефремова, 2000] трактует понятие «восхищение» как высшую степень проявления радости, состояние очарованности кем-либо, чем-либо, восторг. В большом толковом словаре русского языка С.А. Кузнецова «восхищение» - высшая степень удовлетворения, удовольствия от чего-либо; восторг [Кузнецов, 2008, с. 153]. В толковом словаре русского языка Д.В. Дмитриева [Дмитриев, 2003] «восхищением» называется чувство радости и обожания, которое испытывает человек, когда что-либо или кто-либо производит на него очень сильное впечатление своей красотой, совершенством, умом, талантом и т.п. В большом толковым словаре русских существительных Л.Г. Бабенко «восхищение» - чувство высокой степени удовлетворения, удовольствия от чего-либо, высокой оценки кого-либо, чего-либо, сильный подъем радостных чувств [Бабенко, 2009, с. 354]. Русский толковый словарь В.В. Лопатина и Л.Е. Лопатиной [Лопатин, 2013] дает следующее объяснение: высшее удовлетворение, восторг. Толковый словарь русского языка Д.Н. Ушакова [Ушаков, 1935-1940] объясняет значение слова как чувство радостного удовлетворения, состояние очарованности, восторг.

Изучив толкование понятия «восхищение»в русских словарях, представим характеристики определений по частоте их употребления. Понятие «восхищение» определяется в первую очередь как степень проявления какого-либо состояния, чувства. Основные и наиболее употребляемые характеристики для определения понятия «восхищения» это: восторг, удовлетворение и радость. Также «восхищение» объясняется как удовольствие и очарованность. Наименее встречаемая характеристика - обожание присутствует лишь в одном словаре. Анализ близкородственных лексем (восхищать, восхищаться, восхищенно) дает те же самые результаты.

Семантические компоненты слова проявляются через характер его сочетаемости с согласованными и несогласованными определениями. Анализ национального корпуса русского языка [Национальный корпус русского языка, URL] показывает, что наиболее распространенными в использовании являются следующие слова: искреннее, всеобщее, невольное, полное. Было отмечено, что 
большинство используемых при формулировке дефиниций слов также используются в качестве определений к анализируемому слову: восторженное, чувственное, приятное, чудесное, почтительное. К словам, раскрывающим семантическую природу анализируемого понятия, относятся восторг, чувство, удовольствие, очарованность, обожание. Реальное речевое употребление характеризуется высокой степенью дублирования исходных признаков «восхищения». В то же время обнаружено достаточно много определений, которые находятся за пределами списка дублируемых слов. Все эти определения раскрывают дополнительные ситуативные авторские признаки понятия. Они же характеризуют то ассоциативное поле, в котором данное понятия находится.

Для того чтобы определить, как понятие «восхищение» передается в китайском языке, были проанализированы три русскокитайских словаря, которые в первом значении предлагают перевод слова «восхищение» как 《赞赏》 (zànshăng). Чтобы убедиться в правильности выбора варианта перевода, были использованы китайско-русские словари. «Шанхайский» китайско-русский словарь [Ся Чжунъи, 2010, с. 1598] предлагает перевод 《赞赏》 (zànshăng) - восхититься кем/чем (восхищение). Онлайн-версия Большого китайско-русского словаря [БКРС, 2016] переводит «赞赏》 (zànshăng) как: 1) восхищаться, восторгаться, восхвалять; хвалить и вознаграждать; 2) высоко ценить, придавать большое значение, отдавать должное. Также в разделе «Эмоции и чувства» данная совокупность иероглифов имеет значение «восхищение».

Таким образом, в китайском языке слово «восхищение» обозначается системой двух иероглифов «赞赏》 (zànshăng), и в дальнейшем исследовании мы будем пользоваться именно этим значением.

Согласно онлайн-версии Большого китайско-русского словаря БКРС [БКРС, 2016], каждый иероглиф по отдельности имеет следующие значения: «赞》 - 1) помогать, содействовать; 2) превозносить, прославлять, хвалить, восхвалять; одобрять (чтол.); восхищаться (чем-л.); 3) лит. похвала, восхваление. «赏»1) жаловать, награждать; 2) хвалить, превозносить; 3) находить удовольствие в (чем-л.), восхищаться (чем-л.), любоваться (чем-л.); 4) награда, подарок. 
В современном китайском словаре [Шеншу Дин, 2005, с. 1697] дается следующее определение слову «восхищение»: «赞美赏识》похвала; достойная оценка чему-либо.

В толковом словаре китайского языка Синьхуа [Вэй Цзягун, 2016] «восхищение/восхищаться» это: «称美赏识》 - значит одобрять, превозносить; оценивать по достоинству что-либо.

Онлайн-словарь китайского языка «Zdic» [Zdic, 2016] определяет понятия «восхищение/восхищаться»как: 《得到人们的赞赏和高度评价 » - получить одобрение и высокую оценку окружающих.

Большой китайско-русский словарь БКРС [БКРС, 2016] дает трактовку понятия «восхищение», аналогичную данной в словаре «Zdic», в дополнение к тому предлагая пример употребления в предложении: 《老师对你的作品赞赏不已》 - Учитель бесконечно восхищался вашей работой.

В соответствии с поисковой системой «Baidu»[Baidu, 2016] 《восхищение» это: 《赞赏是汉语词汇, 拼音, 解释为赞同, 欣赏, 钦佩》одобрение чего-Л., чувство эстетического наслаждения, уважение, преклонение.

Большой словарь китайского языка [漢語大詞典, 2016] дает следующую трактовку слову «восхищение»: 《贊美賞識》- похвала, достойная оценка чему-либо.

В словаре китайского национального языка Гоюй (Zho-Zho) [Гоюй Дзидиань, 2013] «восхищение» это: 《欣赏而赞美》 эстетическое наслаждение, похвала.

Так, в китайском языке «восхищение» определяется как достойная или высокая оценка чему-либо, одобрение, похвала. Данные характеристики определяются наибольшей частотностью употребления среди предложенных дефиниций. Такие признаки как наслаждение менее употребляемы в словарях. Также для описания «восхищения» используются такие характеристики как превознесение, уважение и преклонение и в определениях встречаются однократно.

Для выявления наибольшей типичной сочетаемости, рассмотрим все согласованные и несогласованные определения, которые используются с анализируемым словом в китайском языке [Национальный корпус китайского языка, 2016]. Наиболее употребляемыми определениями в речи оказались следующие: 非常 (чрезвычайное), 广泛 (широкое, большое), 高度 (высокое), 热烈 (теплое).

Из всего списка слов, используемых при формулировке дефиниций, в качестве определения к анализируемому понятию 
применяется лишь одно: 高度 (gāodù, высокое). Таким образом, в китайском языке употребление в живой речи слова «восхищение» с определениями, входящими в состав словарных статей, встречается редко. Понятие «赞赏》 несет в себе большую смысловую нагрузку, которая не требует дублирования исходных признаков анализируемого понятия. Анализ близкородственных лексем представляется невозможным, поскольку строй китайского языка не предполагает наличие словообразовательных моделей.

Из выявленных характеристик понятия «восхищение» по словарным статьям в русском и китайском языках ни один из показателей не совпадает, что позволяет говорить о том, что в данных лингвокультурах восприятие смысла анализируемого понятия отличается. В русском языке в большинстве толковых словарей «восхищение» отождествляется с «восторгом». В китайском языке «восхищение» приравнивается к достойной (высокой) оценке кому / чему-либо.

Подводя итог, можно сделать следующие выводы: чтобы коммуникация была успешной, в первую очередь необходимо наладить контакт с собеседником, и комплимент является наиболее эффективным методом. Комплимент несет в себе эмотивный смысл, в котором выражается восхищение отличительными особенностями адресата.

Для русского языка «восхищение» - это, прежде всего, выражение положительных эмоций по отношению к человеку, объекту либо явлению, которые отличаются некими выдающимися свойствами или чертами. В китайском языке «восхищение» также является эмоцией, которая несет в себе положительный характер выражения. Однако оно ассоциируется с отличными от русского языка понятиями. Разница в реальном речевом употреблении «восхищения» говорит о том, что данное понятие имеет разную смысловую нагрузку в обоих языках. Для русского языка свойственно использование определений, дополняющих смысл выражения восхищения как эмоции, в то же время в китайском языке «восхищение» «赞赏》 редко требует использования определяющих его слов.

\section{Литература}

Иванова М.Г. Традиционные особенности русских и китайских именных формул в контексте межкультурной коммуникации // Филология и человек. 2017. № 3 . 
Салахова А.Р., Дань Ма Функционирование выражений-комплиментов в русском и китайском языках // И.А. Бодуэн де Куртенэ и мировая лингвистика. Казань, 2015.

Чертыкова М.Д. Восторг и восхищение по-хакасски (семантико-когнитивный анализ глагола морсын - «восторгаться», «восхищаться») // Филология и человек. 2017. № 3.

\section{Словари и источники}

Бабенко Л.Г. Большой толковый словарь русских существительных. М., 2009. М., 1991.

Горбачевич К.С. Словарь современного русского литературного языка.

Даль В.И. Толковый словарь живого великорусского языка. М., 2001.

Дмитриев Д.В. Толковый словарь. М., 2003.

Евгеньева А.П. Малый академический словарь. М., 1957-1960.

Ефремова Т.Ф. Современный толковый словарь русского языка. М., 2000.

СПб., 2008.

Кузнецов С.А. Новейший большой толковый словарь русского языка.

Лопатин В.В., Лопатина Л.Е. Толковый словарь современного русского языка. M., 2013.

Национальный корпус русского языка. [Электронный ресурс].

URL: http://www.ruscorpora.ru.

Ожегов С.И. Толковый словарь русского языка. М., 2011.

Ушаков Д.Н. Толковый словарь русского языка. М., 1935-1940.

Большой китайско-рvсский словарь (БКРС). [Электронный ресурс].

URL: http://bkrs.info/slovo.php?ch=赞赏.

Большой словарь китайского языка (漢語大詞典). [Электронный ресурс].

URL: http://dic.academic.ru/dic.nsf/chi_big_enc/418981/赞赏.

Вэй Цзягун. «Синьхуа»: словарь иероглифов. [Электронный ресурс].

URL: http://xh.5156edu.com.

Национальный корпус китайского языка. [Электронный ресурс].

URL: http://www.cncorpus.org.

Словарь государственного Тайваньского языка Гоюй (Zho-Zho).

[Электронный ресурc]. URL: http://taiwan_simple.enacademic.com/131410/赏赞

Ся Чжунъи. «Шанхайский» китайско-русский словарь. Пекин, 2010.

Шеншу Дин. Словарь современного китайского языка. Пекин, 2005.

«Baidu» (Байдупедия): китайская поисковая система. [Электронный ресурс].

URL: http://hanyu.baidu.com.

«Zdic»: словарь китайского языка. [Электронный ресурс].

URL: http://www.zdic.net.

\section{References}

Ivanova M.G. Tradicionnye osobennosti russkih i kitajskih imennyh formul $v$ kontekste mezhkul'turnoj kommunikacii [Traditional Features of Russian and Chinese Nominal Formulas in the Context of Intercultural Communication]. Filologiya $i$ chelovek [Philology and Man]. 2017. No. 3.

Salahova A.R., Dan' Ma Funkcionirovanie vyrazhenij-komplimentov v russkom $i$ kitajskom yazykah [Functioning of Compliment Expressions in Russian and Chinese]. 
I.A. Boduehn de Kurteneh i mirovaya lingvistika [I.A. Baudouin de Courtenay and World Linguistics]. Kazan', 2015.

Chertykova M.D. Vostorg $i$ voskhishchenie po-hakasski (semantiko-kognitivnyj analiz glagola morsyn - "vostorgat'sya», "voskhishchat'sya») [Delight and Admiration in Khakass (semantic-cognitive analysis of the verb morsyn - "admire")]. Filologiya $i$ chelovek [Philology and Man]. 2017. No. 3.

\section{Dictionaries and sources}

Babenko L.G. Bol'shoj tolkovyj slovar' russkih sushchestvitel'nyh [Great Explanatory Dictionary of Russian Nouns]. Moscow, 2009.

Gorbachevich K.S. Slovar' sovremennogo russkogo literaturnogo yazyka [Dictionary of Modern Russian Literary Language]. Moscow, 1991.

Dal' V.I. Tolkovyj slovar' zhivogo velikorusskogo yazyka [Explanatory Dictionary of the Living Great Russian Language]. Moscow, 2001.

Dmitriev D.V. Tolkovyj slovar' [Explanatory Dictionary]. Moscow, 2003.

Evgen'eva A.P. Malyj akademicheskij slovar' [Small Academic Dictionary]. Moscow, 1957-1960.

Efremova T.F. Sovremennyj tolkovyj slovar' russkogo yazyka [Modern Explanatory Dictionary of the Russian Language]. Moscow, 2000.

Kuznecov S.A. Novejshij bol'shoj tolkovyj slovar' russkogo yazyka [The Newest Large Dictionary of the Russian Language]. St. Petersburg, 2008.

Lopatin V.V., Lopatina L.E. Tolkovyj slovar' sovremennogo russkogo yazyka [Explanatory Dictionary of Modern Russian Language]. Moscow, 2013.

Nacional'nyj korpus russkogo yazyka [National Corpus of the Russian Language].

URL: http://www.ruscorpora.ru.

Ozhegov S.I. Tolkovyj slovar' russkogo yazyka [Explanatory Dictionary of the Russian Language]. Moscow, 2011.

Ushakov D.N. Tolkovyj slovar' russkogo yazyka [Explanatory Dictionary of the Russian Language]. Moscow, 1935-1940.

Bol'shoj kitajsko-russkij slovar' (BKRS) [Large Chinese-Russian Dictionary].

URL: http://bkrs.info/slovo.php?ch=赞赏.

Bol'shoj slovar' kitajskogo yazyka (漢語大詞典) [Big Chinese Dictionary].

URL: http://dic.academic.ru/dic.nsf/chi_big_enc/418981/赞赏.

Vehj Czyagun. «Sin'hua»: slovar' ieroglifov [«Xinhua» Dictionary of Hieroglyphs]. URL: http://xh.5156edu.com.

Nacional'nyj korpus kitajskogo yazyka [National Corpus of Chinese].

URL: http://www.cncorpus.org.

Slovar' gosudarstvennogo Tajvan'skogo yazyka Goyuj (Zho-Zho) [Goyu State Taiwanese Dictionary]. URL: http://taiwan_simple.enacademic.com/131410/赏赞.

Sya Chzhun"i. "Shanhajskij» kitajsko-russkij slovar' [ "Shanghai» Chinese-Russian Dictionary]. Pekin, 2010.

Shenshu Din. Slovar' sovremennogo kitajskogo yazyka. [Dictionary of Modern Chinese]. Pekin, 2005.

«Baidu» (Bajdupediya): kitajskaya poiskovaya Sistema [Baidu (Baidupedia):

Chinese Search Engine]. URL: http://hanyu.baidu.com.

«Zdic»: slovar' kitajskogo yazyka [«Zdic»: Chinese Dictionary].

URL: http://www.zdic.net. 